\title{
Effect of Organic and Inorganic Sources on Quality Parameters of Garlic
}

\author{
Anil Kumar Patle, S. S. Singh, Mahendra Jadia* and Krapal Singh Verma \\ Mahatma Gandhi Chitrakoot Gramodaya Vishwa Vidyalaya, Chitrakoot, District Satna, \\ Madhya Pradesh, India \\ *Corresponding author
}

\section{A B S T R A C T}

\section{Keywords \\ FYM, Goat manure, Plant, Stages \\ Article Info \\ Accepted: \\ 12 December 2020 \\ Available Online: \\ 10 January 2021}

The experiment was carried out to find out the Effect of organic and inorganic sources on quality parameters of garlic. The treatment combinations involving four levels of inorganic fertilizers i.e.Control-C1, 100\% RDF- N:P:K:S(100:60:60:45 kg NPKS/ha) -C2, 75\% RDF- N:P:K:S (75:45:45:33.75 kg NPKS/ha)-C3 and 50\% RDF- N:P:K:S(50:30:30:22.5 $\mathrm{kg}$ NPKS/ha)-C4 four levels of organic manures i.e.Control-O1, FYM@ 15 t/ha-O2, Vermicompost@ 5 t/ha -O3 and Goat manure@ 5 t/ha-O4 were given in G-50 of garlic variety. TSS content of bulb ( ${ }^{\circ}$ Brix), chlorophyll content in leaves (Spad value) and volatile oil content in bulb (\%) were observed by the maximum at 30,60,90, and $120 \mathrm{DAS}$ were observed under the treatment $\mathrm{C}_{2} \mathrm{O}_{2} 100 \%$ RDF- N:P:K:S(100:60:60:45 kg NPKS/ha) +FYM@15 t/ha, at all the growth stages.

\section{Introduction}

Garlic (Allium sativum L.), grown at commercial level is a spices crop and is of a bulbous spice category. In India it is second most widely consumed spice after onion. However, it is as valuable all over the world as it is in our country.

The name Garlic is derived from the English word 'gar' meaning spear, referred to the clove. As far as its origin is considered it is from Central Asia, from where it spread to Mediterranean region. It is grown for medicinal usage in pharmaceutical industry also. Garlic belongs to the Alliaceae family. It is herbaceous annual. The underground developed part of the Garlic plant is edible stem and is known as Bulb.

Garlic clove or simply Garlic is rich in protein, calcium, magnesium, phosphorus, potassium, and carbohydrates. The freshly peeled garlic cloves contains $62.8 \%$ moisture, $29 \%$ carbohydrate, $6.3 \%$ protein, $1 \%$ mineral matter, $0.8 \%$ fibre, $0.1 \%$ fat, $1 \%$ total ash, $0.03 \%$ calcium, $0.31 \%$ phosphorus, $0.0001 \%$ iron, $0.4 \mathrm{mg} / 100 \mathrm{~g}$ nicotinic acid and 13 $\mathrm{mg} / 100 \mathrm{~g}$ vitamin ' $\mathrm{C}$ '.

The bulb contains a colorless, odorless water soluble amino acid Allin. On crushing the garlic bulb, the enzyme allinase breaks down Allin to produce allicin of which the principle 
ingredient is the odoriferous diallyldisulphide. This Allicin is major component which produce flavor in the Garlic. Garlic contains about $0.1 \%$ volatile oil. The main constituents of the oil are diallyldisulphide (60\%), diallyltrisulphide (20\%), allyl propyl disulphide $(6 \%)$, a small quantity of a diethyl disulphide and probably diallylpolysulphide.

Medicinally, Allicin in the Garlic reduces cholesterol concentration in human blood (Shankaracharya, 1974). Since Vedic era Garlic has therapeutic value and every Indian home was prescribed garlic based effective treatment for many common ailments.

In India it is grown in 281 thousand hectare producing 1617 thousand MT with average productivity of 5.75 tones per hectare (Anonymous, 2017). The largest producer of Garlic in the world is China. The largest Garlic producing state in India is Madhya Pradesh, it is grown in about 81 thousand hectare with total production of 424 thousand MT giving an average production of 5.23 tones per hectare.

In Madhya Pradesh, Garlic is grown in large scale in Mandsaur, Ratlam, Neemuch, Shajapur and Ujjain (Malwa region). Garlic production has given a good earning to the farmers in this region. Madhya Pradesh and Rajasthan produces 49.5 percent of Garlic of the country. The important garlic growing states in India are Madhya Pradesh, Rajasthan, Gujarat, Uttar Pradesh and Orissa. Garlic production percentage in different states is around in Madhya Pradesh (26.25\%), Rajasthan (23.34\%), Gujarat (19.67\%) and in Uttar Pradesh (12\%).

The organic farming makes positive contribution not only to the soil and environment but human health also. Hence, to eliminate all these bad effects, integrated plant nutrient farming is best alternative.
Integration of chemical fertilizers with organic manures and biofertilizers are able to maintain the soil health, productivity and fertility. Organically grown food is expected to fetch higher price and this can offset any loss due to lower yields.

\section{Materials and Methods}

The present experiment was carriedout in the Research Farm, Department of Horticulture, Mahatma Gandhi Chitrakoot Gramodaya Vishwa Vidyalaya, Chitrakoot, District Satna (M.P.). $\mathrm{C}_{1} \mathrm{O}_{1}$ Control + Control, $\mathrm{C} 1 \mathrm{O} 2$ Control+FYM@15t/ha, $\mathrm{C}_{1} \mathrm{O}_{3}$ Control + Vermicompost @ 5 t/ha, C1 O4 Control + Goat manure @ 5 t/ha, $\mathrm{C}_{2} \mathrm{O}_{1}$ 100\% RDF$\mathrm{N}: \mathrm{P}: \mathrm{K}: \mathrm{S}(100: 60: 60: 45 \quad \mathrm{~kg} \quad \mathrm{NPKS} / \mathrm{ha}) \quad+$ Control, $\quad \mathrm{C}_{2} \quad \mathrm{O}_{2} \quad 100 \% \quad$ RDFN:P:K:S(100:60:60:45 kg NPKS/ha)+FYM@ $15 \quad \mathrm{t} / \mathrm{ha}, \quad \mathrm{C}_{2} \quad \mathrm{O}_{3} \quad 100 \% \quad$ RDF$\mathrm{N}: \mathrm{P}: \mathrm{K}: \mathrm{S}(100: 60: 60: 45 \quad \mathrm{~kg} \quad$ NPKS/ha) + Vermicompost @ 5 t/ha, $\mathrm{C}_{2} \mathrm{O}_{4}$ 100\% RDF$\mathrm{N}: \mathrm{P}: \mathrm{K}: \mathrm{S}(100: 60: 60: 45 \mathrm{~kg} \mathrm{NPKS} / \mathrm{ha})+$ Goat manure @ 5 t/ha, $\mathrm{C}_{3} \mathrm{O}_{1} \quad 75 \%$ RDF$\mathrm{N}: \mathrm{P}: \mathrm{K}: \mathrm{S}(75: 45: 45: 33.75 \mathrm{~kg} \quad \mathrm{NPKS} / \mathrm{ha}) \quad+$ Control, $\quad \mathrm{C}_{3} \quad \mathrm{O}_{2} \quad 75 \% \quad$ RDF$\mathrm{N}: \mathrm{P}: \mathrm{K}: \mathrm{S}(75: 45: 45: 33.75 \quad \mathrm{~kg} \quad \mathrm{NPKS} / \mathrm{ha}) \quad+$ FYM @ 15 t/ha, $\mathrm{C}_{3} \quad \mathrm{O}_{3} \quad 75 \%$ RDF$\mathrm{N}: \mathrm{P}: \mathrm{K}: \mathrm{S}(75: 45: 45: 33.75 \quad \mathrm{~kg} \quad \mathrm{NPKS} / \mathrm{ha})+$ Vermicompost @ 5 t/ha, $\mathrm{C}_{3} \mathrm{O}_{4} 75 \%$ RDF$\mathrm{N}: \mathrm{P}: \mathrm{K}: \mathrm{S}(75: 45: 45: 33.75 \mathrm{~kg}$ NPKS/ha) + Goat manure @ 5 t/ha, $\mathrm{C}_{4} \quad \mathrm{O}_{1} \quad 50 \%$ RDF$\mathrm{N}: \mathrm{P}: \mathrm{K}: \mathrm{S}(50: 30: 30: 22.5 \quad \mathrm{~kg} \quad \mathrm{NPKS} / \mathrm{ha}) \quad+$ Control, $\quad \mathrm{C}_{4} \quad \mathrm{O}_{2} \quad 50 \% \quad$ RDF$\mathrm{N}: \mathrm{P}: \mathrm{K}: \mathrm{S}(50: 30: 30: 22.5 \mathrm{~kg}$ NPKS/ha) + FYM @ $15 \quad \mathrm{t} / \mathrm{ha}, \quad \mathrm{C}_{4} \quad \mathrm{O}_{3} \quad 50 \% \quad \mathrm{RDF}-$ $\mathrm{N}: \mathrm{P}: \mathrm{K}: \mathrm{S}(50: 30: 30: 22.5 \quad \mathrm{~kg} \quad \mathrm{NPKS} / \mathrm{ha})+$ Vermicompost @ 5 t/ha, $\mathrm{C}_{4} \mathrm{O}_{4} 50 \%$ RDF$\mathrm{N}: \mathrm{P}: \mathrm{K}: \mathrm{S}(50: 30: 30: 22.5 \mathrm{~kg}$ NPKS/ha)+ Goat manure @ 5 t/ha were given in G-50 variety. The climate of the region is semi-arid and sub-tropical having extreme winter and summer. During the winter months, the temperature drops down to as low as $2^{\circ} \mathrm{C}$ while in the summer months the temperature 
extend above $47^{\circ} \mathrm{C}$, hot desiccating winds (Loo) are regular symptom during summers while, there may be infrequent spell of frost during the winter months. The soil of the investigation field was clay loam with good drainage and uniform texture with medium NPK status. Observations were recorded according to standard procedure on TSS content of bulb ( ${ }^{\circ}$ Brix), chlorophyll content in leaves (Spad value) and volatile oil content in bulb $(\%)$.

\section{Results and Discussion}

The data revealed that significantly maximum TSS content of bulb ( ${ }^{\mathrm{O}}$ Brix $)$ were recorded in the treatment $\mathrm{O}_{2}$ (FYM@15 t/ha) followed by $\mathrm{O}_{3}$ (Vermicompost@ $5 \mathrm{t} / \mathrm{ha}$ ). While, the TSS content of bulb ( ${ }^{\circ}$ Brix) was observed lowest in the treatment $\mathrm{O}_{1}$ (Control) during both the years. Application of FYM might have the ability to increase the availability of other nutrients like nitrogen, phosphorus and potassium probably due to higher rate of mineralization and favorable condition for microbial and chemical activity, which in turn increased the N,P, K and TSS content of bulb. Another reason might be the increased activity of nitrate reductive enzymes which helped in synthesis of certain amino acids and protein as reported by Ali et al.,2018, Kumar et al., 2019 and Ansary et al., 2006. As regards to chemical fertilizers, the treatment $\mathrm{C}_{2}$ (100\% RDF- N:P:K:S (100:60:60:45 kg NPKS/ha)) was observed significantly maximum TSS content of bulb( $\left(^{\circ}\right.$ Brix $)$, however, minimum was observed in treatment $\mathrm{C}_{1}$ (control) during both the years. The accumulation of higher ascorbic acid content in the bulb might be correlated with the increased activity of nitrate reductase which helped in synthesis of certain amino acids and proteins. These results are also corroborated by the findings of Kumar et al., 2019

Interaction effect was significantly affected the TSS content of bulb ( ${ }^{\circ}$ Brix) in all the years and pooled. The significantly maximum TSS content of bulb ( ${ }^{\mathrm{O}}$ Brix) were recorded in treatment combination $\mathrm{O}_{2} \mathrm{C}_{1}$ (FYM@15 t/ha+ 100\% RDF- N:P:K:S (100:60:60:45 kg NPKS/ha)) While, it was recorded lowest in treatment combination $\mathrm{O}_{1} \mathrm{C}_{1}$ (control + control) during both the years. Improvement in quality attributes of onion due to integration of organic manure and inorganic fertilizers as well as integration among organic sources could be attributed to better and balanced nutrition and production of growth promoting substances by organics which might have led to better quality like enhanced TSS content of bulb. These results are also corroborated by the findings of Ram et al., (2017).

The data revealed that significantly maximum chlorophyll content in leaves (Spad value) were recorded in the treatment $\mathrm{O}_{2}$ (FYM@ 15 t/ha) followed by $\mathrm{O}_{3}$ (Vermicompost@ 5 t/ha). While, the chlorophyll content in leaves (Spad value) was observed lowest in the treatment $\mathrm{O}_{1}$ (Control) at both the stages during both the years. Among organic sources could be attributed to better and balanced nutrition and production of growth promoting substances by organics which might have led to better quality like chlorophyll content in leaves.

These results were corroborated with the findings of Kumar et al., 2019. As regards to chemical fertilizers, the treatment $\mathrm{C}_{2}(100 \%$ RDF- N:P:K:S (100:60:60:45 kg NPKS/ha)) was observed significantly maximum chlorophyll content in leaves (Spad value), however, minimum was observed in treatment $\mathrm{C}_{1}$ (control) at both the stages during both the years. These results are also corroborated by the findings of Verma et al., 2013 and Kumar et al., (2019). 
Table.1 Effect of organic and inorganic sources on TSS content of bulb ( ${ }^{\circ}$ Brix), chlorophyll content in leaves (Spad) and volatile oil content in bulb (\%) of garlic

\begin{tabular}{|c|c|c|c|c|c|c|c|c|c|}
\hline \multirow[t]{2}{*}{$\begin{array}{c}\text { Treatment } \\
\text { Symbols }\end{array}$} & \multicolumn{3}{|c|}{ TSS content of bulb $\left({ }^{0}\right.$ Brix $)$} & \multicolumn{3}{|c|}{$\begin{array}{c}\text { Chlorophyll content in leaves } \\
\text { (Spadvalue) }\end{array}$} & \multicolumn{3}{|c|}{ Volatile oil content in bulb (\%) } \\
\hline & $\mathbf{1}^{\text {st }}$ year & $2^{\text {nd }}$ year & Pooled & $\mathbf{1}^{\text {st }}$ year & $2^{\text {nd }}$ year & Pooled & $\mathbf{1}^{\text {st }}$ year & $2^{\text {nd }}$ year & Pooled \\
\hline $\mathbf{C}_{1} \mathbf{O}_{1}$ & 25.67 & 26.00 & 25.83 & 83.67 & 84.00 & 83.83 & 0.39 & 0.40 & 0.40 \\
\hline $\mathrm{C}_{1} \mathbf{O}_{2}$ & 30.67 & 31.00 & 30.83 & 102.27 & 102.60 & 102.43 & 0.56 & 0.57 & 0.57 \\
\hline $\mathrm{C}_{1} \mathbf{O}_{3}$ & 28.67 & 29.00 & 28.83 & 98.67 & 99.00 & 98.83 & 0.46 & 0.47 & 0.47 \\
\hline $\mathrm{C}_{1} \mathbf{O}_{4}$ & 28.67 & 29.00 & 28.83 & 95.67 & 96.00 & 95.83 & 0.45 & 0.46 & 0.46 \\
\hline $\mathbf{C}_{2} \mathbf{O}_{1}$ & 27.67 & 28.00 & 27.83 & 89.67 & 90.00 & 89.83 & 0.41 & 0.42 & 0.42 \\
\hline $\mathrm{C}_{2} \mathrm{O}_{2}$ & 34.00 & 34.33 & 33.83 & 103.67 & 104.00 & 103.83 & 0.62 & 0.63 & 0.63 \\
\hline $\mathrm{C}_{2} \mathrm{O}_{3}$ & 32.67 & 33.00 & 32.83 & 103.37 & 103.70 & 103.53 & 0.60 & 0.61 & 0.61 \\
\hline $\mathrm{C}_{2} \mathrm{O}_{4}$ & 29.67 & 30.00 & 29.83 & 100.67 & 101.00 & 100.83 & 0.49 & 0.50 & 0.50 \\
\hline $\mathrm{C}_{3} \mathrm{O}_{1}$ & 27.67 & 28.00 & 27.83 & 90.67 & 91.00 & 90.83 & 0.41 & 0.42 & 0.42 \\
\hline $\mathrm{C}_{3} \mathrm{O}_{2}$ & 33.67 & 34.00 & 33.67 & 103.57 & 103.90 & 103.73 & 0.60 & 0.61 & 0.61 \\
\hline $\mathrm{C}_{3} \mathrm{O}_{3}$ & 32.67 & 33.00 & 32.83 & 103.17 & 103.50 & 103.33 & 0.59 & 0.60 & 0.60 \\
\hline $\mathrm{C}_{3} \mathrm{O}_{4}$ & 29.67 & 30.00 & 29.83 & 98.87 & 99.20 & 99.03 & 0.48 & 0.49 & 0.49 \\
\hline $\mathrm{C}_{4} \mathrm{O}_{1}$ & 26.67 & 27.00 & 26.83 & 87.67 & 88.00 & 87.83 & 0.40 & 0.41 & 0.41 \\
\hline $\mathrm{C}_{4} \mathrm{O}_{2}$ & 31.67 & 32.00 & 31.83 & 102.67 & 103.00 & 102.83 & 0.57 & 0.58 & 0.58 \\
\hline $\mathrm{C}_{4} \mathrm{O}_{3}$ & 30.67 & 31.00 & 30.83 & 101.67 & 102.00 & 101.83 & 0.54 & 0.55 & 0.55 \\
\hline $\mathrm{C}_{4} \mathrm{O}_{4}$ & 28.67 & 29.00 & 28.83 & 93.67 & 94.00 & 93.83 & 0.43 & 0.44 & 0.44 \\
\hline SE(m) & 0.439 & 0.441 & 0.443 & 1.007 & 1.028 & 1.087 & 0.012 & 0.011 & 0.010 \\
\hline $\mathrm{CD}_{5 \%}$ & 1.259 & 1.263 & 1.268 & 2.884 & 2.944 & 3.113 & 0.034 & 0.031 & 0.028 \\
\hline
\end{tabular}


Interaction effect was significantly affected the chlorophyll content in leaves (Spad value). The significantly maximum chlorophyll content in leaves (Spad value) were recorded in treatment combination $\mathrm{O}_{2} \mathrm{C}_{1}$ (FYM@ 15 t/ha+ 100\% RDF- N:P:K:S (100:60:60:45 kg NPKS/ha)) While, it was recorded lowest in treatment combination $\mathrm{O}_{1} \mathrm{C}_{1}$ (control + control)at both the stages during both the years Improvement in quality attributes of onion due to integration of organic manure and inorganic fertilizers as well as integration among organic sources could be attributed to better and balanced nutrition and production of growth promoting substances by organics which might have led to better quality like chlorophyll content in leaves. These results were corroborated with the findings of Ram et al., 2017 and Mohd et al., (2011).

The data revealed that significantly maximum volatile oil content in bulb (\%) were recorded in the treatment $\mathrm{O}_{2}$ (FYM@ $15 \mathrm{t} / \mathrm{ha}$ ) followed by $\mathrm{O}_{3}$ (VERMICOMPOST@ $5 \mathrm{t} / \mathrm{ha}$ ). While, the volatile oil content in bulb (\%) was observed lowest in the treatment $\mathrm{O}_{1}$ (CONTROL) during both the years. The probable cause may be due to increased availability of nitrogen and phosphorus leads to increased volatile oil content in bulb. These results were corroborated with the findings of Kumar et al., 2019. As regards to chemical fertilizers, the treatment $\mathrm{C}_{2}(100 \%$ RDF$\mathrm{N}: \mathrm{P}: \mathrm{K}: \mathrm{S}$ (100:60:60:45 kg NPKS/ha)) was observed significantly maximum volatile oil content in bulb (\%), however, minimum was observed in treatment $\mathrm{C}_{1}$ (control) during both the years. The accumulation of higher ascorbic acid content in the bulb might be correlated with the increased activity of nitrate reductase which helped in synthesis of certain amino acids and proteins. These results are also corroborated by the findings of Kumar et al., 2019
Interaction effect was significantly affected the volatile oil content in bulb (\%). The significantly maximum volatile oil content in bulb (\%) were recorded in treatment combination $\mathrm{O}_{2} \mathrm{C}_{1}$ (FYM@ 15 t/ha+ 100\% RDF- N:P:K:S(100:60:60:45 kg NPKS/ha)) While, it was recorded lowest in treatment combination $\mathrm{O}_{1} \mathrm{C}_{1}$ (control + control)during both the years. Improvement in quality attributes of onion due to integration of organic manure and inorganic fertilizers as well as integration among organic sources could be attributed to better and balanced nutrition and production of growth promoting substances by organics which might have led to better quality like enhanced volatile oil content in bulb. These results are also corroborated by the findings of Kumar et al., 2019.

\section{References}

Ansary, S.A. Choudhary, J. and Jarkar, S (2006). Post-harvest studies of onion (Allium cepa L.) grown under different moisture regimes and fertilizer levels. Crop. Res. Hissar, 31(3):404-407.

Acharya Somen and Kumar Hitesh (2018). Effect of Some Organic Manure on Growth and Yield of Garlic in Greenhouse Condition at Cold Desert High Altitude Ladakh Region, Defence Life Science Journal, Vol. 3, No. 2, April 2018, pp. 100-104.

Ali Usman, Ram R.B., Srivastava Abhijeet, Pandey Raj, Singh Bijendra K and Singh Himanshu (2018). Effect of organic manures and varieties on growth, yield and quality traits of garlic (Allium sativum L.), Journal of Pharmacognosy and Phytochemistry 2018; 7(6): 40-42.

Joshi, R.P. Rajoria, U.K. and Bose, U.S. (2005). Influences of nitrogen and sulphur application on growth, and yield of onion (allium cepaL.).Nat. Sem. on 
agro - tech., quality,processing and export of spices, p. 64.

Kumar Anil, Ram R. B., Maji Sutanu, Kishor Sachin, Yadav Rahul, Govind, Ram Kamal Meena (2017). Effect of Organic Manures, Biofertilizers and Micronutrients on Growth, Yield and Quality of Onion (Allium cepaL.).Vol 13, No 2 (2017).

Kumar Sanjay,Naruka I.S., Shaktawat R.P.S., Singh O.P. and Meena K.C.(2019). Response of Garlic (Allium sativum L.) to Organic and Inorganic Fertilizers. International Journal of Agriculture Sciences, Volume 11( 7), pp.- 82098211.

Mohd T. A.,., Desai, J.D., Parmar, S.B. and Parmar, B.R. (2011). Effect of organic and inorganic fertilizers on growth, yield and quality of garlic cv GG.-1, Asian J. Hort., 6 (1): 52-55.

Nainwal R.C., Singh D, Katiyar R.S., Sharma L and Tewari S.K. (2015). Response of garlic to integrated nutrient management practices in a sodic soil of Uttar Pradesh, India, Journal of Spices and
Aromatic Crops Vol. 24 (1): 33-36.

Patil M. B., Shitole D. S., Shinde S. B. and Purandare N. D. (2007). Response of garlic to organic and inorganic fertilizers, J. Hort. Sci. Vol. 2 (2): 130133.

Ram NiwasYadav, H.L. Bairwa and Gurjar, M.K. (2017). Response of Garlic (Allium sativum L.) to Organic Manures and

Fertilizers.Int.J.Curr.Microbiol.App.Sci. 6(10): 4860-4867.

Sachin A.J., Bhalerao P.P. and Patil S.J. (2017). Effect of organic and inorganic sources of nitrogen on growth and yield of garlic (Allium sativum L.) var. GG-4, International Journal of Chemical Studies 2017; 5(4): 559-562.

Verma S, Choudhary M.R., Yadav B.L. and Jakhar M.L. (2013). Influence of vermicompost and sulphur on growth and yield of garlic (Allium sativum L.) under semi arid climate, Journal of Spices and Aromatic CropsmVol. 22 (1): 20-23.

\section{How to cite this article:}

Anil Kumar Patle, SS. Singh, Mahendra Jadia and Krapal Singh Verma. 2021. Effect of Organic and Inorganic Sources on Quality Parameters of Garlic. Int.J.Curr.Microbiol.App.Sci. 10(01): 1089-1094. doi: https://doi.org/10.20546/ijcmas.2021.1001.132 